were offered. The papers of P. E. Ellis and W. J. Stower on movements of hopper bands of the desert locust showed that there may be some common features in the behaviour of adults and that of hoppers.

A session on "Locust Phases" began with a review by J. S. Kennedy (Cambridge) of the recent approaches to the problem with emphasis on the endocrinological and behavioural aspects of phase variation. Papers by F. O. Albrecht (Laboratoire de Biologie Animale, Paris), P. E. Ellis and P. HunterJones (Anti-Locust Research Centre) illustrated the great amount of laboratory work that is being done on many aspects of the biology, morphology, physiology and behaviour of the phases. Perhaps the greatest need suggested by these papers and the subsequent diseussion of them is for basic physiological knowledge to link together the results of widely separated experimental approaches to the problem. R. E. Blackith (Imperial College, London) and D. E. Davies (Anti-Locust Research Centre) spoke on the application of statistical methods, in particular the generalized-distance method, to the analysis of phase variation in locust populations.

The research that is being done on control methods was described and discussed under the heading "Control Development", with Dr. D. L. Gunn (International Red Locust Control Service) in the chair. It ranges from field investigation of the use of aircraft against swarms, hopper bands and eggfields to laboratory work on problems such as the cumulative effect of sub-lethal doses of insecticides, the comparative toxicity of different materials and formulations, and the comparative susceptibility of species and stages of locusts. The principal speakers included R. D. MacCuaig (Anti-Locust Research Centre) and J. H. Lloyd (International Red Locust Control Service), the former dealing with laboratory research and the latter with the various methods, including spraying adult locusts from light aircraft, used for controlling the red locust in its outbreak areas near Lake Tanganyika.

Papers by Z. Waloff, R. Skaf (Syria), R. C. Rainey, G. B. Popov and W. J. Stower, on "The Desert Locust Problem", emphasized a fact suggested at many of the previous talks, that the desert locust remains the most difficult of the plague locusts from the point of view of both research and control. The lack of clearly definable outbreak areas, the very long-range migrations of which the insect is capable, the possibility of continued nomadic existence of swarms in small numbers during interplague periods, and the large number and diversity of countries affected by it, all conspire to complicate the problem, but also to make it most challenging to research workers. B. Zolotarevsky (International African Migratory Locust Control Organization) spoke on some unusual seasonal movements of swarms of the desert locust in West Africa.

The final session, on "Trends and Needs in Locust Research", was introduced by T. H. C. Taylor (Anti-Locust Research Centre) in a talk designed to illustrate the gaps in present-day knowledge revealed by the preceding sessions. In the discussion which followed, two main trends were apparent. These were, on one hand, a call for more physiological research relating to sensory physiology, internal physiological states and the relation of such states to behaviour and to phases; and on the other hand, the treatment of the problem quantitatively from the point of view of population dynamics and ecology.
This gathering was the first for which locust research workers assembled solely to exchange views and discuss current work, previous locust conferences having been largely concerned with matters of international co-operation and control arrangements. Its success was undoubtedly due to the informal atmosphere, which encouraged the airing of unconventional and tentative proposals, and thus helped to enliven the discussions. Perhaps the emergence of several tentative and controversial theories may reduce the empiricism which has perforce formed such a large part of locust research hitherto. The Anti-Locust Research Centre, under its director, Dr. B. P. Uvarov, who took the chair at most of the sessions, is to be congratulated on initiating this stimulating review of current research on locusts.

P. T. HASKELL

\section{COLONIAL STUDENTS IN GREAT BRITAIN}

$T$ HE inquiry conducted by Political and Economic Planning (PEP) into Colonial students in Great Britain* had as its practical aim to discover whether any changes in approach or organization on the part of the authorities concerned might lead to a more effective use of the resources devoted to the education and training of men and women from the Colonial territories, and to make constructive suggestions where necessary. The general implications have been discussed elsewhere in Nature, but the inquiry, supplemented by questionnaire, interview and field work, and the detailed information about scholarship holders kept by the Colonial Office, brought to light concrete facts and figures which are not otherwise easily available. These facts, on which the main recommendations are based, are presented in one chapter of the report and in the appendixes, and in their collection PEP was guided by four main considerations : the interest which the student or his sponsors has in the use to be made of his education ; the possible wish for him to acquire more than a qualification or purely professional skill ; the requirements of the society from which the student comes; and the effect which the education of Colonial students in Britain may have upon relations between Britain and the Colonial territories.

The grand total of Colonial students in the United Kingdom and the Republic of Ireland on January 1, 1955, was 10,200, but this includes 2,040 student nurses who are otherwise excluded from these statistics. In 1939 there were about four hundred Colonial students at British universities with an unknown number at other institutions. Ten years later the combined total was 3,300 , of whom 1,745 were university students. For the academic year 1954-55, there were 8,160 students, of whom 2,915 were university students; but although in 1953 nearly a tenth of university students in Britain were overseas students, only one-fifth of these, or about 2 per cent of the total, were from the Colonial territories. While, however, the number of university students in Britain is slightly decreasing, the number of students coming from the Colonial territories is increasing, and, since 1950, the number of postgraduate Colonial students has become significant. During the academic year 1954-55 nearly one-third

* Colonial Students in Britain : a Report by PEP. Pp. ix +257, (London: Political and Economic Planning, 1955.) 218. 
of Colonial students in Britain were Nigerians, about one-tenth came from the Gold Coast, and a small group from Sierra Leone and Gambia. More than one-fifth came from the Far East--Malaya, Singapore, Hong Kong, Sarawak and North Borneo-about one-eighth from East and Central Africa, and another eighth from the West Indies, the remaining one-tenth coming from Cyprus, Malta, Gibraltar, Mauritius, Fiji, the Seychelles and the other Colonies of the British Commonwealth. Every Colony has to-day more students in Britain than it had six years ago, but since 1949 Nigeria has replaced the West Indies as the largest single group and, with the Far East territories, has outstripped all the others in the rate of growth.

By far the greatest number of Colonial students who go abroad from their homeland go to the United Kingdom, but many go to other Commonwealth countries, including India, Australia, New Zealand and Canada. The last-named has more than six hundred Colonial students in its universities, and more than four hundred Nigerians are now studying in the United States. Some have gone to the Netherlands, and the Gold Coast Cocoa Marketing Board in 1953-54 placed about forty medical students in Germany. Colonial students are mostly older than their British fellow-students, usually between twenty and thirty, about 10 per cent of those interviewed being thirty-one years of age or more ; most African students are between twenty-five and thirty. About a quarter of those interviewed were married, and nearly half of them had their wives or husbands with them in Britain; these figures are regarded as typical. About one-half had reached School Certificate standard, a quarter had taken Higher Certificate, an Intermediate degree or a first M.B. ; about onetwentieth had graduated, and one-tenth had some form of professional or trade qualification. The gap between the date of their last examination at home and the commencement of their studies in Britain is often considerable, sometimes several years. About one-third of the Colonial students hold scholarships, although the proportion is much smaller than in 1949. For Gold Coast students the proportion in the academic year 1954-55 was two-fifths.

Scholars outnumber private Colonial students in agriculture, forestry, veterinary science, education, teaching diploma, social sciences, public administration, railway training and Post Office training courses, and they account for about a third of those taking architecture, medicine, pharmacy, printing and science. Three-quarters of all Colonial students take one of eight courses : law (18 per cent) ; engineering (14 per cent) ; medicine (12 per cent); allied medical subjects like dentistry ( 3 per cent); arts subjects (6 per cent) ; preliminary studies to qualify for the desired course (10 per cent); education and teacher training ( 10 per cent); and science (5 per cent). The largest group (law) has 1,451 students, and the smallest (science) 378. Except for nursing, law is the course with the largest number of registrations, but although a much higher proportion of West Africans study law at a university than of any other group of Colonial students, there are, relative to their numbers, fewer West Africans at the Inns of Court than any other group. The percentage of Colonial students who take a further degree appears to be slightly higher than that of British students. Little is known about the part-time students (probably several hundred in number); but the inquiry suggests that, while this group occasionally throws up a first-rate scholar, such students generally experience great difficulties with their studies and sometimes lose heart and abandon them. Just over a third of Colonial students are at universities and university colleges, about one-eighth are at the Inns of Court, and the rest mainly at polytechnies, and technical and training colleges. In 1955 more than a half were in London, only about 3 per cent at Oxford and Cambridge, about 27 per cent in the English provinces, 7 per cent in Scotland, 2 per cent in Wales and 7 per cent in Northern Ireland and the Republic of Ireland. Most of the women are student nurses; but excluding nurses, women students constitute just over one-sixth of all Colonial students, and about one-third are at universities.

\section{COMMONWEALTH OBSERVATORY, CANBERRA}

\section{REPORT FOR 1954}

$\mathrm{T}$ HE report for 1954 of the Commonwealth Observatory, Canberra*, follows the usual course, dealing with the work of the Observatory under eleven main headings, the first of which includes time service and positional astronomy, described under five sub-sections. Time signals were sent out from the Observatory four times each day, the average correction for the transmitted signal being $21 \mathrm{~m} . \mathrm{sec}$. and the average daily change in these corrections $2.2 \mathrm{~m}$.sec. Under astrophysical investigations are included magnitude sequences, variable stars, nebulæ and clusters, stellar atmospheres, stellar spectroscopy and Mars. With regard to nebulæ and clusters, it is announced that the photographic survey of both the Magellanic Clouds has been completed with an Ektar camera. Star counts in and around the Small Cloud to magnitude 14 and 16 provide new evidence on the structure and population characteristics of the Cloud. It has been established that the cepheids in the Large Cloud, as in the Small Cloud, are much bluer than the galactic cepheids. The survey of bright southern galaxies with the Reynolds reflector is about 90 per cent complete and about 110 plates were obtained on twenty-eight nights, bringing the total to 270 , of which 170 have been measured for types and diameters, and a few for luminosity distribution in some large spirals.

Under the heading of telescopes and equipment, it is satisfactory to know that the major components of the 74-in. reflector have been erected, the final assembly only awaiting the completion of the dome which, with the optical parts, arrived early in the year. The erection of the Yale-Columbia 26-in. refractor has been commenced and will be completed as soon as the dome is finished. The old clock-drive will be replaced by an electronic diurnal drive, and provision has been made for a Selsyn repeater which will indicate declination settings to 2 of arc. The Munich zenith telescope, installed in May, has since been in constant use by the Munich observers. An iris diaphragm photometer is in operation, and preliminary trials are being made on plates obtained with the Zeiss instrument.

In the account of buildings, it is mentioned that the assembly for the 74-in. and Yale-Columbia

* Commonwealth Observatory, Canberra. Report of the Commonwealth Astronomer for the Year 1954. Pp. 8. (Canberra : Cormmonwealth Observatory, 1955.) 